\section{The International Seismological Summary}

THE International Seismological Summary for January, February and March, 1934, has just been received. Apart from individual studies of earthquakes it gives the final determinations of the epicentres and starting times of all earthquakes sufficiently recorded at seismological observatories to make such determinations reasonable. The criterion has now been made "three consistent observations of $P$ and $S$ " to justify the determination. During the first quarter of 1934 there were 127 earthquakes whose epicentres were found; 47 of these were new and 80 were repetitions from old epicentres, showing the tendency of earthquakes to recur in any one place where an earthquake had once happened. All except six of the earthquakes had a normal depth of focus. The six exceptions were all of deep focus. The deepest recorded earthquake during the quarter was on January 18, 1934, with a depth of focus of 0.09 of the earth's radius, or about 360 miles. Its epicentre was lat. $22^{\circ} \mathrm{S}$., long. $180^{\circ}$, which is in the Pacific Ocean to the south of the Fiji Islands, a well-established zone for deepfocus earthquakes.

\section{Recent Earthquakes}

THREE earthquakes of considerable severity have recently been recorded at European observatories, and a fourth has been experienced. The first was on April 13 and was recorded at De Bilt (Holland) at $6 \mathrm{~h} .34 \mathrm{~m}$. 56s. G.M.T. The epicentre was at a distance of rather more than $20^{\circ}$ from De Bilt. The second was registered at De Bilt on April 16 at 6h. $19 \mathrm{~m} .30 \mathrm{~s}$. and at Kew at $6 \mathrm{~h} \cdot 19 \mathrm{~m} \cdot 33 \mathrm{~s}$. G.M.T. Dr. G. van Dyk considers that the epicentre of this shock was likely to have been in the region of the Aleutian Islands. It gave rise to ground amplitudes of $0.031 \mathrm{~mm}$. at Kew. The third shock, which caused ground amplitudes of $0.05 \mathrm{~mm}$. at Kew, was registered there on April 16 at $6 \mathrm{~h}$. $54 \mathrm{~m}$. 53s. G.M.T. It also appears to have originated near the Aleutian Islands. The fourth earthquake was felt on the night of April 26 at Gropperia in Calabria, Italy. The same shock was felt at Soverto and Vivo Valentia, but no damage was done. Calabria has been the scene of intense seismic activity on numerous occasions in the past; but notably between February 5 and March 27, 1783, when 181 towns and villages were completely destroyed and more than 30,000 people killed. These Calabrian earthquakes were, according to Lyell, "the first example of a region visited, both during and after the convulsions, by men possessing sufficient leisure, zeal, and scientific information to enable them to collect and describe with accuracy such physical facts as throw light on geological questions".

\section{Announcements}

AfTer due consideration, it has been decided not to abandon the next meeting of the Australian and New Zealand Association for the Advancement of Science, which is due to be held in Adelaide in August. The meeting will, however, be shorter than usual and few of the normal social engagements will be included. The meeting is expected to commence on August 12 and end on August 16. The incoming president will be Dr. Patrick Marshall, testing officer in the Public Works Department, New Zealand, in succession to the late Sir Ernest Scott, whose death last year was a severe blow to the Association.

ThE following officers of the North East Coast Institution of Engineers and Shipbuilders have recently been elected : President, Mr. W. A. Woodeson ; Vice-Presidents, Mr. J. Ramsay Gebbie, Mr. N. M. Hunter and Mr. John Neill; Hon. Treasurer, Mr. W. H. Pilmour.

Messrs. Frederick Warne \& Co., Ltd., Chandos House, Bedford Court, Bedford Street, London, W.C.2, have published a leaflet giving advice on how to assist in saving the lives of wild birds around our coasts, which have landed in patches of oil and have become helpless. The leaflet can be obtained free of charge.

AN arrangement has been made between Messrs. Newton and Co., of 72 Wigmore Street, London, W.1, and Messrs. Newton and Co., Ltd., of 43 Museum Street, London, W.C.1, under which the two businesses, which until twenty years ago were one, will be amalgamated, The former manufacture optical lanterns, epidiascopes, projection microscopes and similar instruments, while the latter are well known as manufacturers of lantern slides and lantern filmstrip. The combined firms will carry on business under the style of Newton and Co., Ltd., and for a short time both branches will continue at their respective addresses, after which the whole business will be transferred to the Museum Street address.

The Coopers Hill War Memorial Prize and Medal, which was founded by members of the Royal Indian Engineering College, Coopers Hill, in commemoration of members of the College who fell during the War of 1914-18, is awarded annually by the Institution of Civil Engineers and triennially in turn by the Institution of Electrical Engineers, the School of Military Engineering, Chatham, and the School of Forestry, Oxford. The prize consists of $(a)$ a bronze medal, (b) a parchment certificate of award, and (c) a money prize of the value of about $£ 20$. The triennial award falls this year to the Institution of Electrical Engineers, which has decided to invite members to submit for consideration a paper on any subject coming within the scope of electrical science or electrical engineering and their applications. Further information can be obtained from the Secretary, Institution of Electrical Engineers, Savoy Place, Victoria Embankment, London, W.C.2.

Dr. K. R. Popper has pointed out a misprint in his letter "Interpretation of Nebular Red-Shifts" published in Nature of January 13, p. 69. Formula (1) should read : " $(d \lambda / \lambda)_{T+\Delta T}=\left(\Delta c_{T} / T\right)_{T+\Delta T}$ ". Formula (7) is not very clear as printed; it should read: " $\nu_{\tau}=\nu_{p} d T_{\tau} / d \tau=\nu_{p} e^{\tau / T_{P}}$ ". 